Note: This is a post-peer-review, pre-copyedit version of an article published in Journal of Business Ethics. The final authenticated version is available online at: https://doi.org/10.1007/s10551-019-04416-0

\title{
ANTECEDENTS OF ENVIRONMENTALLY AND SOCIALLY RESPONSIBLE SUSTAINABLE CONSUMER BEHAVIOR
}

Short title: RESPONSIBLE SUSTAINABLE CONSUMER BEHAVIOR

\author{
Maja Hosta, M.A. \\ Faculty of Economics, University of Ljubljana, Slovenia \\ Vesna Zabkar, Ph.D.* \\ Faculty of Economics, University of Ljubljana, Slovenia
}

*Corresponding author: Kardeljeva pl.17, 1000 Ljubljana, Vesna.zabkar@ef.uni.lj.si,

\begin{abstract}
Responsible sustainable consumer behavior (RSCB) involves a complex pattern of environmental and social issues, in line with the view of sustainability as a construct with both environmental and social pillar. So far, environmental dimension was far more researched than social dimension. In this article, we investigate the antecedents of both environmentally and socially RSCB and willingness to behave in environmentally/socially responsible way. We include measures of concern, perceived consumer control/effectiveness, personal/social norms and ethical ideologies/obligation to better explain and extend the traditional theory of planned behavior. Additionally, we test the impact of information availability about environmental or social impact on RSCB. Our findings on a representative
\end{abstract}


sample of 426 respondents (ages 18 to 65) show that in general, antecedents of environmentally and socially responsible sustainable consumption are similar in their effect on consumer behavior, with personal norms, concern and ethical ideologies having the strongest impact on RSCB. When comparing both types of behavior, socially responsible behavior is more influenced by perceived behavioral control and possibly social norms than environmentally responsible behavior, while information availability plays its role for both behaviors. Sustainable responsible consumption can be achieved by embracing both dimensions of sustainability and consumers need to have a sense for both social and environmental issues. The complexity and struggles between doing what is good for environment and society could be the reason why consumers have difficulties achieving sustainable responsible consumption.

Keywords: responsible sustainable behavior, concern, perceived control, personal/social norms, ethical ideologies

\section{INTRODUCTION}

Global development is now more than ever threatened by unsustainable patterns of consumption and production (United Nations Environment Programme, 2015). Since 1987 when the first report by the World Commission on Environment and Development was published, sustainable development has been defined as development that is "trying to meet the needs of current generations without compromising the ability of future generations to meet their own needs". Three pillars of sustainability have been identified as the building blocks of sustainable development, namely environmental, social and economic. Different and distinct sustainability performance measures and standards were developed to measure environmental, social and economic performance of companies (Chabowski, Mena, \& Gonzalez-Padron, 2011). 
This view of sustainability as a construct of three separate pillars was well aligned to the managerial view of triple bottom line, since it created a well-defined and transparent method for performance evaluations. (Choi \& Ng, 2011) observed that literature 'does not offer an examination of the notion that different dimensions of sustainability can exist in the minds of consumers' (p. 270). Environmental and social dimension are often not well defined and thus their "relative importance" is not evaluated (Choi \& Ng, 2011, p. 271). Recently, more researchers are increasingly taking into account the multidimensionality of the sustainability construct. Research by Catlin et al. (2017) shows that consumers perceive the social and environmental dimensions of sustainability as psychologically distinct and align the social dimension of sustainability with local, short term and affective reflections while the environmental dimension with global, long-term and cognitive thoughts. More productoriented research includes multidimensionality by comparing competing/substitute products of organic, local and fair trade ethical alternatives (Frank \& Brock, 2019). More research is still needed with regard to questions whether consumers act differently when behaving in environmentally or socially responsible way, how do environmentally and socially responsible behaviors differ regarding their antecedents; whether marketers need to separate environmental and social appeals and how can they create successful sustainability programs that are aligned to consumer sustainability needs and wants.

The aim of this paper is thus to look at antecedents of environmentally and socially responsible sustainable behavior to estimate their relative importance, differences and similarities. To find the answers needed we conducted a mixed methods research (Brannen, 2005), including personal interviews with consumers (Study 1) and quantitative research and administered survey questionnaire (Study 2). The operationalization of constructs for quantitative research was supported by qualitative research. In the paper we first look at the literature on responsible and sustainable consumption and combine the findings with in-depth 
consumer interviews to develop specific hypotheses. We use the findings from our qualitative research mainly to complement environmental topics, which were more thoroughly covered in the literature, with social dimensions' findings. Then we present the models of environmentally and socially responsible sustainable behavior and its antecedents based on theory of planned behavior (concern, perceived control/effectiveness, personal/social norms, and ethical obligation) which were tested using a representative sample of consumers. Our main contribution thus lies in identifying and empirically testing two dimensions of sustainable responsible behavior by including several explanatory variables relating to willingness to act and (reported) sustainable responsible behavior for both sustainability dimensions. We operationalize several constructs for socially responsible behavior and extend the theory of planned behavior with constructs showing more other-oriented concerns thus addressing some of the limitation of the TPB model. As Roberts (1995, p. 104) observes, “Assessing a person's SRCB on only a social or ecological dimension would be akin to trying to solve a puzzle with half of its pieces."

\section{RESPONSIBLE SUSTAINABLE CONSUMER BEHAVIOR AND SUSTAINABILITY DIMENSIONS (ENVIRONMENTAL, SOCIAL)}

Early conceptualizations and operationalizations of responsible consumer behavior heavily favored the environmental dimension (Antil, 1984; Kinnear, Taylor, \& Ahmed, 1974; Webster Jr, 1975). 'Green' consumerism, as one of the first specified responsible behaviors, was quite commonly seen as part of socially responsible consumption (Roberts, 1995), even though the emphasis was always on environmental rather than social issues. A mixture of poorly defined behaviors without equal representation of environmental and social issues resulted in a rather narrow view of consumer responsibility. 
Later authors did, however, start to make a distinction between socially and environmentally conscious consumption (Mayer, 1976) but were using them interchangeably or merging them under one construct (e.g. Belch, 1982). Roberts (1995) was one of the first to make a clearer distinction between environmental and social concerns and proposed a two-dimensional scale (social and environmental) for measuring responsible consumer behavior. Building on his work, (Webb, Mohr, \& Harris, 2008) also clearly distinguished between the social and environmental dimensions of responsible behavior and concluded that among the existing measures "none is an up-to-date measure of consumer behaviors in response to a full range of social issues" (p. 2). They developed a new measure, called Socially Responsible Purchase and Disposal, based on a definition of socially responsible consumer as "a person basing his or her acquisition, usage, and disposition of products on a desire to minimize or eliminate any harmful effects and maximize the long-run beneficial impact on society" (Mohr, Webb, \& Harris, 2001, p. 47).

With further developments, ethical responsibility has arisen as a social and corporate responsibility issue. 'Green' consumption was usually seen as a predecessor or one of its parts (Freestone \& McGoldrick, 2008), combined with issues like animal welfare, which could not be placed under the 'green' banner, and other issues connected with morality, as well as the general norms and values of society. This is reflected in a definition of ethical consumers as those "influenced by environmental, social justice, human health, and animal welfare issues in choosing products and services encompassing, alongside with fair trade goods, 'sweat-free' clothes, 'cruelty-free' cosmetics, energy efficient appliances, and organic foods" (Low \& Davenport, 2005). Research on ethical consumption also presented some different and new antecedents compared to environmentally or socially responsible sustainable consumption. Seeing those issues all becoming part of ethics has created an illusion that environmental and social issues are equally represented, although Choi \& Ng in 2011 still observed that a "lack 
of attention to sustainability, as a concept with multiple dimensions, has presented a developmental gap in green marketing literature, sustainability, and marketing literature for decades" (p. 269).

In the past decade and even more recently, interest arose again, especially since organic grocery buying options are entering mainstream consumption decisions. New conceptualizations and operationalizations of sustainable responsible behavior are emerging, better capturing the multidimensionality of the sustainability concept. Balderjahn, Buerke, Kirchgeorg, Peyer, Seegebarth, \& Wiedmann (2013) developed measurement model for consumer consciousness for sustainable consumption with three dimensions, namely environmental, social and economic. Sudbury-Riley \& Kohlbacher (2016) conceptualize ethically minded consumer behavior with five factors and add (to environmental and social behaviors) also recycling, paying a price premium and boycotting for ethical reasons. Studies measuring purchasing behaviors of responsible consumers (as opposed to non-consumption behaviors, e.g. energy conservation) are usually evaluating product categories, such as organic foods, for measuring "green consumption" (Ngobo, 2011, Van Doorn \& Verhoef, 2015, deMagistris, \& Gracia, 2016, Frank \& Brock, 2019), while fair trade has commonly been seen as part of socially responsible consumption (de Pelsmacker \& Janssens, 2007, Frank \& Brock, 2019). Some authors have aimed to assess "competitive situation of the ethical grocery market” (p. 598, Frank \& Brock, 2019). They find fair trade products as complementary products, while local and organic groceries as substitutes to each other when consumers buy “green” (Frank \& Brock, 2019).

Other researchers have observed more psychological distinctions between different dimensions of sustainability. Catlin et al. (2017) found consumers use more affective or emotive words and signs when describing concern for social dimension of sustainability, while concern about the environment is often described with more cognitive or analytical 
language. Additionally, social dimension of sustainability is associated with short-term and local factors, while the environmental dimension with more long-term and global considerations. Thus, socially concerned consumers could be more inclined to satisfy their immediate needs and environmentally concerned consumers to use more rational decisionmaking and budget restraint considerations (Catlin et al., 2017). Besides including sustainability dimensions in their research, some authors also combine it with additional concept of self (health and safety) vs. other (e.g. support local economy) related motives for behavior (Frank \& Brock, 2019) and combine it with perceived value concept (Currás-Pérez, Dolz-Dolz, Miquel-Romero \& Sánchez-García, 2018).

The summary of recent studies on sustainable and responsible consumer behavior and positioning of our paper is outlined in Table 1. Our paper aims to investigate consumer behavior that includes considerations of environment (nature) and social environment (other people and society) when purchasing a product. We follow definitions of Epstein (2008) saying sustainable consumer behavior can be defined as behavior based on awareness of the long-term consequences of an individual behavior for the natural or social environment. We add responsibility concept defined as an intention to act based on the acknowledgement of one's duties toward self or others (Schrader, 2007). Nonetheless, since existing consumer practices are mostly unsustainable or weakly sustainable (Lorek \& Spangenberg, 2014), we are interested not just in what consumer chooses/uses/owns (e.g. organic food). We are interested in a pattern of self and other oriented considerations (attitudes, norms, ethical ideologies), first leading to intentions and combined with the right information to sustainable responsible consumption (e.g. choosing something that is least harmful). Thus, a responsible sustainable consumer is someone who carefully weights what s/he truly needs and considers also how this will affect others (nature, society). S/he has a developed positive attitude, ethical 
considerations and norms, is willing to behave and actually behaves in sustainable and responsible way. 
Table 1: Recent studies on sustainable and responsible consumer behavior

\begin{tabular}{|c|c|c|c|c|c|c|}
\hline & $\begin{array}{l}\text { Research } \\
\text { design }\end{array}$ & $\begin{array}{l}\text { Underlying } \\
\text { theory }\end{array}$ & $\begin{array}{l}\text { Data and } \\
\text { sample size }\end{array}$ & $\begin{array}{l}\text { Sustainability } \\
\text { dimensions }\end{array}$ & $\begin{array}{l}\text { Measures included } \\
\text { (main) }\end{array}$ & Findings \\
\hline & & & & Environmental Social & & \\
\hline $\begin{array}{l}\text { Balderjahn, } \\
\text { Buerke, } \\
\text { Kirchgeorg, } \\
\text { Peyer, } \\
\text { Seegebarth, } \\
\& \\
\text { Wiedmann } \\
(2013) \\
\end{array}$ & $\begin{array}{l}\text { Research } \\
\text { paper } \\
\text { (quant. } \\
\text { study) }\end{array}$ & $\begin{array}{l}\text { Scale } \\
\text { development, } \\
\text { expectancy- } \\
\text { value model }\end{array}$ & $\mathrm{n}=368$ & $\mathrm{X}$ & $\begin{array}{l}\text { Consumer } \\
\text { consciousness for } \\
\text { sustainable } \\
\text { consumption (CSC) }\end{array}$ & $\begin{array}{l}\text { Developed concept and measurement model for } \\
\text { consumer consciousness for sustainable } \\
\text { consumption. Consciousness was operationalized } \\
\text { as combination of consumer personal beliefs and } \\
\text { concerns for different sustainability dimensions. } \\
\text { Three dimensions for CSC (ENV, SOC, ECON) } \\
\text { are proposed and ECON construct with three sub } \\
\text { dimensions. }\end{array}$ \\
\hline $\begin{array}{l}\text { Van Doorn } \\
\text { \& Verhoef } \\
(2015)\end{array}$ & $\begin{array}{l}\text { Research } \\
\text { paper } \\
\text { (quant. } \\
\text { study) }\end{array}$ & $\begin{array}{l}\text { Cost-benefit } \\
\text { approach, } \\
\text { micro-economic } \\
\text { theory }\end{array}$ & $\begin{array}{l}\text { Scanner data } \\
\text { for } 28 \text { product } \\
\text { categories, } \\
1246 \\
\text { households }\end{array}$ & $\mathrm{X}$ & $\begin{array}{l}\text { Actual purchase } \\
\text { behavior, values, } \\
\text { supply side variables } \\
\text { (price, promotional } \\
\text { intensity, distribution, } \\
\text { vice, virtue, fresh), } \\
\text { consumer level } \\
\text { variables (values, } \\
\text { attitudes, } \\
\text { sociodemographics) }\end{array}$ & $\begin{array}{l}\text { Findings show organic products are less popular } \\
\text { in some categories (e.g. high promotional } \\
\text { intensity) and more popular in others (e.g. fresh). } \\
\text { Biospheric values drive organic purchases and } \\
\text { altruistic values do not. Quality and health } \\
\text { motives drive organic purchases in certain } \\
\text { categories (e.g. low promotional intensity). } \\
\text { Egoistic values and price consciousness have } \\
\text { negative effect on organic purchases. }\end{array}$ \\
\hline $\begin{array}{l}\text { Sudbury- } \\
\text { Riley \& } \\
\text { Kohlbacher } \\
(2016)\end{array}$ & $\begin{array}{l}\text { Research } \\
\text { paper } \\
\text { (quant. } \\
\text { study) }\end{array}$ & $\begin{array}{l}\text { Scale } \\
\text { development, } \\
\text { theory of } \\
\text { planned } \\
\text { behavior }\end{array}$ & $\mathrm{n}=1278$ & $\mathrm{X}$ & $\begin{array}{l}\text { Ethically minded } \\
\text { consumer behavior } \\
(\text { EMCB) }\end{array}$ & $\begin{array}{l}\text { Scale conceptualizes ethically minded consumer } \\
\text { behavior as a combination of five different factors } \\
\text { of consumption choices and demonstrates } \\
\text { reliability and validity across diverse nations. To } \\
\text { previously known environmental, social and } \\
\text { recycling behaviors, authors add paying a price } \\
\text { premium and boycotting for ethical reasons. }\end{array}$ \\
\hline $\begin{array}{l}\text { Paul, Modi, } \\
\text { \& Patel } \\
(2016)\end{array}$ & $\begin{array}{l}\text { Research } \\
\text { paper } \\
\text { (quant. } \\
\text { study) }\end{array}$ & $\begin{array}{l}\text { Extended } \\
\text { Theory of } \\
\text { planned } \\
\text { behavior }\end{array}$ & $\mathrm{n}=521$ & $\mathrm{X}$ & $\begin{array}{l}\text { Reported intention } \\
\text { (green products in } \\
\text { general), attitude, } \\
\text { concern, PBC, social } \\
\text { norms }\end{array}$ & $\begin{array}{l}\text { Extended TPB has higher predictability than TPB } \\
\text { and TRA for intention to buy green products. } \\
\text { Consumer attitude and perceived behavioral } \\
\text { control significantly predicts purchase intention } \\
\text { whereas subjective norm does not. Additional } \\
\text { construct of concern is positively related and } \\
\text { could be added in future research. }\end{array}$ \\
\hline De- & Research & I & Experimental & $\mathrm{X}$ & Willingness to pay & Findings show PDO labels (regional claim) as \\
\hline
\end{tabular}




\begin{tabular}{|c|c|c|c|c|c|c|c|}
\hline $\begin{array}{l}\text { Magistris, \& } \\
\text { Gracia } \\
(2016)\end{array}$ & $\begin{array}{l}\text { paper } \\
\text { (quant. } \\
\text { study) }\end{array}$ & & $\begin{array}{l}\text { auction } \\
\text { approach } \\
(\mathrm{n}=145)\end{array}$ & & & $\begin{array}{l}\text { (WTP) for three } \\
\text { different food claims } \\
\text { (health-related claim, a } \\
\text { regional claim and an } \\
\text { organic claim) for } \\
\text { cheese products, } \\
\text { consumers' personal } \\
\text { characteristics }\end{array}$ & $\begin{array}{l}\text { most valued, followed by organic and light claim } \\
\text { (health-related). Female respondents were willing } \\
\text { to pay more for regional claims; older preferred } \\
\text { light and those with a university-level education } \\
\text { organic thus influencing their WTP for different } \\
\text { cheeses. }\end{array}$ \\
\hline $\begin{array}{l}\text { Lim } \\
\text { (2017) }\end{array}$ & $\begin{array}{l}\text { Conceptual } \\
\text { article }\end{array}$ & $\begin{array}{l}\text { Model of } \\
\text { mindful } \\
\text { consumption }\end{array}$ & $\begin{array}{l}\text { Literature } \\
\text { review }\end{array}$ & $\mathrm{X}$ & $\mathrm{X}$ & $\begin{array}{l}\text { Responsible } \\
\text { consumption, } \\
\text { anticonsumption and } \\
\text { mindful consumption }\end{array}$ & $\begin{array}{l}\text { Application of three theoretical perspectives of } \\
\text { consumer behavior: responsible consumption, } \\
\text { anticonsumption and mindful consumption. } \\
\text { Author sees environmental, social and ethical } \\
\text { issues all part of responsible consumption } \\
\text { (umbrella term). Author uses examination of } \\
\text { multiple theoretical perspectives which help } \\
\text { researchers gain insight how consumers engage in } \\
\text { sustainable consumption. }\end{array}$ \\
\hline $\begin{array}{l}\text { Catlin et al. } \\
\text { (2017) }\end{array}$ & $\begin{array}{l}\text { Research } \\
\text { paper } \\
\text { (quant. } \\
\text { study) }\end{array}$ & $\begin{array}{l}\text { Consumer } \\
\text { affect/cognition, } \\
\text { psychological } \\
\text { distance } \\
\text { (construal level } \\
\text { theory) }\end{array}$ & $\begin{array}{l}\text { Pilot study } \\
(\mathrm{n}=422), \\
\text { followed by } \\
\text { series of five } \\
\text { quantitative } \\
\text { studies ( } \mathrm{n}= \\
104, \mathrm{n}=60, \\
\mathrm{n}=110, \mathrm{n}=121, \\
\mathrm{n}=58)\end{array}$ & $\mathrm{X}$ & $\mathrm{X}$ & $\begin{array}{l}\text { Cognitive/ affective, } \\
\text { short /long term, local / } \\
\text { global considerations, } \\
\text { characteristics }\end{array}$ & $\begin{array}{l}\text { Defining factors that could show psychological } \\
\text { distinctiveness between social and environmental } \\
\text { perceptions of sustainability among consumers. } \\
\text { Specifically researching factors such as cognitive } \\
\text { vs. affective descriptions, short vs. long term and } \\
\text { local vs. global considerations. Findings show } \\
\text { consumers associate the social dimension of } \\
\text { sustainability more with affective, short-term, and } \\
\text { local considerations and the environmental } \\
\text { dimension more with cognitive, long-term, and } \\
\text { global considerations. }\end{array}$ \\
\hline $\begin{array}{l}\text { Geiger, } \\
\text { Fischer, \& } \\
\text { Schrader } \\
(2018)\end{array}$ & $\begin{array}{l}\text { Conceptual } \\
\text { article }\end{array}$ & $\begin{array}{l}\text { Intent- and } \\
\text { impact-based } \\
\text { research } \\
\text { approaches, } \\
\text { Capability } \\
\text { Approach }\end{array}$ & $\begin{array}{l}\text { Literature } \\
\text { review }\end{array}$ & $\mathrm{X}$ & $\mathrm{X}$ & $\begin{array}{l}\text { SCB-cube, } \\
\text { sustainability } \\
\text { dimension, } \\
\text { consumption phases } \\
\text { and areas, impact }\end{array}$ & $\begin{array}{l}\text { Authors systematize existing research on different } \\
\text { behaviors and present integrative framework in } \\
\text { the form of a three-dimensional cube model of } \\
\text { sustainable consumption behavior (SCB-cube). } \\
\text { They add a fourth impact dimension where they } \\
\text { emphasize ecological vs. socio-economic } \\
\text { dimension. Framework is useful for researchers } \\
\text { measuring and selecting relevant sustainable } \\
\text { consumer behaviors on the individual level. }\end{array}$ \\
\hline Frank \& & Research & Self-perception & Observations & $\mathrm{X}$ & $\mathrm{X}$ & Self, other and & Exploration and analysis of an intention-behavior \\
\hline
\end{tabular}




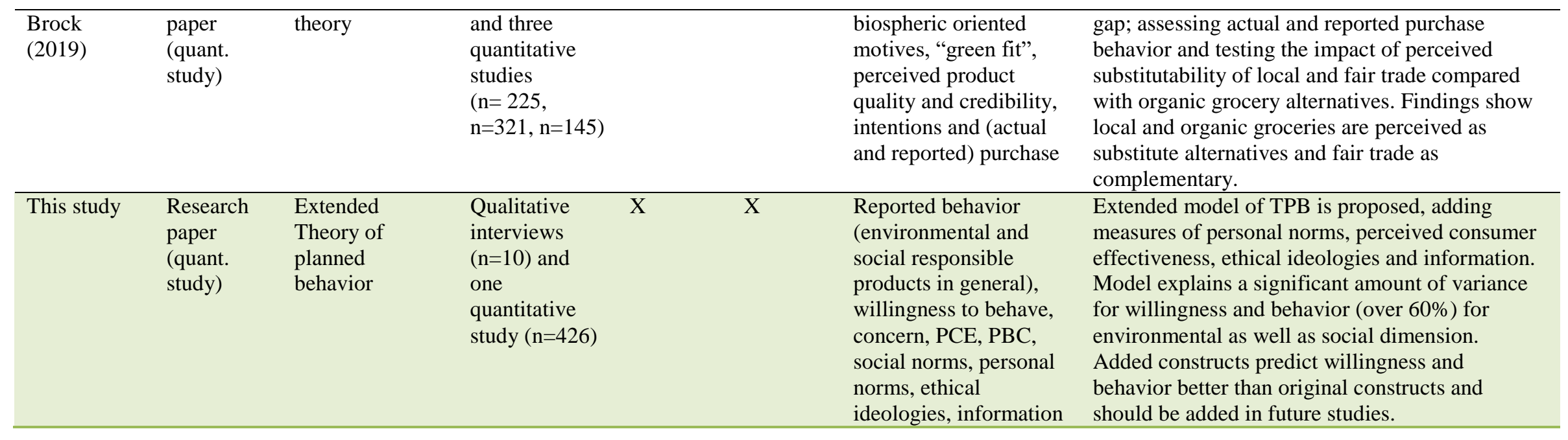




\section{ANTECEDENTS OF RESPONSIBLE SUSTAINABLE CONSUMER BEHAVIOR}

Several researchers have made the observation that throughout the history of research on environmentally and socially responsible sustainable (consumer) behavior, many models have been proposed to explain its antecedents. In line with observations, environmental dimension of behavior was more researched; the same can be said for the antecedents of responsible behavior. Environmental concerns for example, have been researched much more than social concerns (Shaw, Shiu, \& Clarke, 2000).

Early antecedents that were proposed and explored by researches like Antil (1984) and Roberts (1995) included concepts of liberalism, concern, perceived consumer effectiveness and alienation, to understand why and how consumers behave in responsible way. Rational, cognitive component of the behavior was emphasized through these concepts (Park \& Stoel, 2005) and was reflected in the name usually used for such consumers (e.g. environmentally “conscious").

When explaining the process of responsible consumer behavior, theory of planned behavior (Ajzen, 1991) is most commonly used. Researchers continually use the model to explain sustainable behaviors (e.g. Paul, Modi \& Patel, 2016) and are revising the model for future researchers to gain better predictive power using meta-analytic reviews (Han \& Stoel, 2017). It has been used extensively for research of environmentally responsible behavior, while for socially responsible (ethical) behavior its usage is scarce. Shaw et al. (2000) proposed that, when researching broader social and ethical issues, additional factors need to be included, since "traditional model structure without modification is more suited to the prediction of selfinterested behaviors". According to the theory of planned behavior (Ajzen, 1991), the main concepts that need to be included in the model of responsible behavior are intentions, attitudes toward the behavior, subjective (social) norms and perceived behavioral control. 
As Ajzen (1991, p. 181) describes, "A central factor in the theory of planned behavior is the individual's intention to perform a given behavior". It was confirmed many times that antecedent factors do not usually have direct effect on behavior, but are mediated by behavioral intentions (Bamberg \& Moser, 2007). Ajzen (1991, p. 181) describes intentions as "indications of how hard people are willing to try, or how much of an effort they are planning to exert, in order to perform the behavior". Rather than measuring behavior, some researchers have proposed measuring attitudes or intentions with the assumption that both can be good predictors of behavior. This assumption was though quickly disputed with research showing the common gap between intentions/attitudes and behavior (Kollmuss \& Agyeman, 2002), which made behavior the preferable dependent variable, although not easily measured. (Abdul-Muhmin, 2007) suggested that intentions should be substituted by willingness, especially in environments where the availability of environmental facilities and sustainable product alternatives is lower. Therefore, the following hypothesis is projected:

H1: Willingness to behave has positive influence on a) environmentally responsible consumer behavior and b) socially responsible consumer behavior.

Environmental concern was one of the first concepts included in environmental research (Anderson Jr \& Cunningham, 1972; Antil, 1984), intended to explain environmentally responsible behavior. Commonly viewed as a "general attitude" toward problems in natural environment (Abdul-Muhmin, 2007) it can include either positive (interest) or negative (skepticism) assessment of environmental problems (De Pelsmacker \& Janssens, 2007). Environmental concern can also include emotional component of behavior (strong feelings of anger, disappointment) (Lee, 2008) and has been found to predict behavioral intentions (Minton \& Rose, 1997), more than behaviors directly. (Bamberg, 2003), p. 23) has also noticed that environmental concern can also act as a heuristic, helping consumers to "frame 
the decisional problem, the relevant alternatives and the personally salient decision criterion". Factors that increase environmental concern include environmental beliefs (Kilbourne \& Pickett, 2008) and "perceived threats to the global environment", "knowledge of global environmental issues", "past environmentally friendliness" as well as "perceived psychological consequences of environmentally friendliness" (Abdul-Muhmin, 2007). Concerns about broader social, not just environmental issues have been less researched (Shaw et al., 2000), mainly in the context of fair trade consumption (Long \& Murray, 2013). Based on the above, the following hypothesis is suggested:

H2: Concern has a positive and strong impact on a) environmentally responsible willingness to behave and $b$ ) socially responsible willingness to behave.

Perceived control was added as last to the theory of planned behavior, however presents a main distinctive factor from the theory of reasoned action (Ajzen, 1991). It is defined as consumers "perception of the ease or difficulty of performing the behavior of interest" and reflects "past experience as well as anticipated impediments and obstacles" (Ajzen, 1991, p. 183). This construct has proved to be very important in explaining behavior, even directly. It is specific to a certain situation and as such differs from the locus of control, which is a general perception of ones perceived control (Ajzen, 1991). Perceived behavioral control also differs from actual control, although when a person has the right opportunities and resources (time, money, skills, and information), it can also be used as a substitute for actual control. Related to perceived control is another behavioral predictor, perceived consumer effectiveness, which explains consumer's perception of the power to affect the "occurrence or averseness of an event” (Ellen et al., 1991, p. 103).

Based on the above, the following hypotheses are developed: 
H3: Perceived behavioral control has positive influence on a) environmentally responsible willingness to behave and b) socially responsible willingness to behave.

H4: Perceived consumer effectiveness has positive influence on a) environmentally responsible willingness to behave and b) socially responsible willingness to behave.

Norms present a mixture of cognitive, emotional and social factors. In the theory of planned behavior, social (subjective) norms are defined as "perceived social pressure to perform or not to perform the behavior" (Ajzen, 1991, p.188). Although social norms have consistently been added to the theory of planned behavior and successfully explain behavior, researchers recognize also the importance of personal (moral) norms (Shaw, 2000). In the meta-study of pro-environmental behavior, Bamberg \& Moser (2007) found out that "social norms also directly contribute to the development of moral norms". Social norms present "standards" to separate right and wrong behaviors and present "content" for development of personal norms, if and when they are internalized (Bamberg \& Moser, 2007). Social norms are usually used by a person as information on whether certain behavior is acceptable and not necessarily as a push factor of "social pressure" (Bamberg \& Moser, 2007). Feeling of moral obligation then comes from social norms that have been internalized and became personal (moral) norms. Bamberg \& Moser (2007) thus see personal norms as adding the more other-interested (prosocial) component to the theory of planned behavior as opposed to attitudes and perceived behavioral control representing more self-interested motives. Thøgersen (2006) also ads additional insight into the relationship and effectiveness of social and personal norms by saying, "when personal norms are accounted for, the direct effect of subjective social norms on environmentally responsible behavior usually disappears”.

Therefore, the following hypotheses were developed: 
H5: Social norms have relatively weak impact on behavior and have positive influence on a) environmentally responsible willingness to behave and b) socially responsible willingness to behave.

H6: Personal norms have relatively strong impact in both types of behavior and have positive influence on a) environmentally responsible willingness to behave and b) socially responsible willingness to behave.

Theory of planned behavior has gained some criticism since it is more applicable to selfinterested behaviors and fails to incorporate moral judgments. Environmentally responsible consumption was with time seen as more self-interested due to health and status benefits consumers could gain with this type of consumption. Researchers Shaw, Shiu \& Clarke (2000, p. 882) thus suggested to include additional measure in the TPB model: ethical obligation that would capture "an individual's internalized ethical rules, which reflect their personal beliefs about right and wrong". This measure would be a better predictor of otherinterested behavior connected with other ethical issues, like socially responsible behavior or animal welfare, due to less personal benefits a person can gain with this type of behavior. Catlin et al. (2017) additionally found consumers use more affective or emotive words when describing social concerns, showing the importance of including concepts other than merely cognitive. Therefore, the following hypothesis is developed:

H7: Ethical obligations/ideologies have positive influence on a) environmentally responsible willingness to behave and b) socially responsible willingness to behave.

Consumer (especially rational) behavior is also a reflection of the consumer's knowledge and can be influenced by quality and quantity of information (Pelsmacker \& Janssens, 2007) and different types of information that companies can provide to consumers about their social and 
environmental impact (D'Souza, Taghian, \& Lamb, 2006). This is done through the heuristicsystematic model of information processing (Chaiken, 1980) where perceived effort and costs (time, money) associated with information gathering (Saini \& Monga, 2008; Uusitalo \& Oksanen, 2004) play an important role. In environmentally and socially responsible consumption information availability is extremely important and it is also a duty of a consumer to get right information (Schrader, 2007). It plays crucial role for achieving more responsible consumption which requires substantially more efforts on the part of the consumer in their decision making (Shaw \& Shiu, 2003) and usually limits their purchasing freedom. Thus, it has also been noted that a lack of information can be one of the main obstacles when buying responsibly (Dupré, 2005; Leire \& Thidell, 2005). Vermeir \& Verbeke (2006) demonstrated that some situational and individual determinants of behavioral intention, namely involvement, perceived availability, and perceived consumer effectiveness, could be influenced by providing relevant information.

Information can be defined as those given to consumers through different sources (either from company or other organizations or other individuals) and different media/designs (ATL, BTL, labels) about the product's and company's environmental and social impact/actions throughout the life-cycle of a product (from production process to disposal). Although recognized as one of the common obstacles to more responsible behavior, information is rarely included in ethical research with some exceptions in the fair trade context research (De Pelsmacker \& Janssens, 2007). In line with the above:

H8: Information availability has positive influence on a) environmentally responsible consumer behavior and b) socially responsible consumer behavior.

All hypotheses are presented in a conceptual model of antecedents of responsible sustainable behavior (Figure 1). We explore the distinction and parallels between environmentally and 
socially responsible sustainable consumption and antecedents of each specific behavior through the theory of planned behavior where concerns, perceived behavioral control/effectiveness, norms and ethical obligation influence willingness/intentions that consequently lead to behavior (Ajzen \& Fishbein, 2005).

Figure 1: Drivers of environmentally and socially responsible sustainable consumer behavior

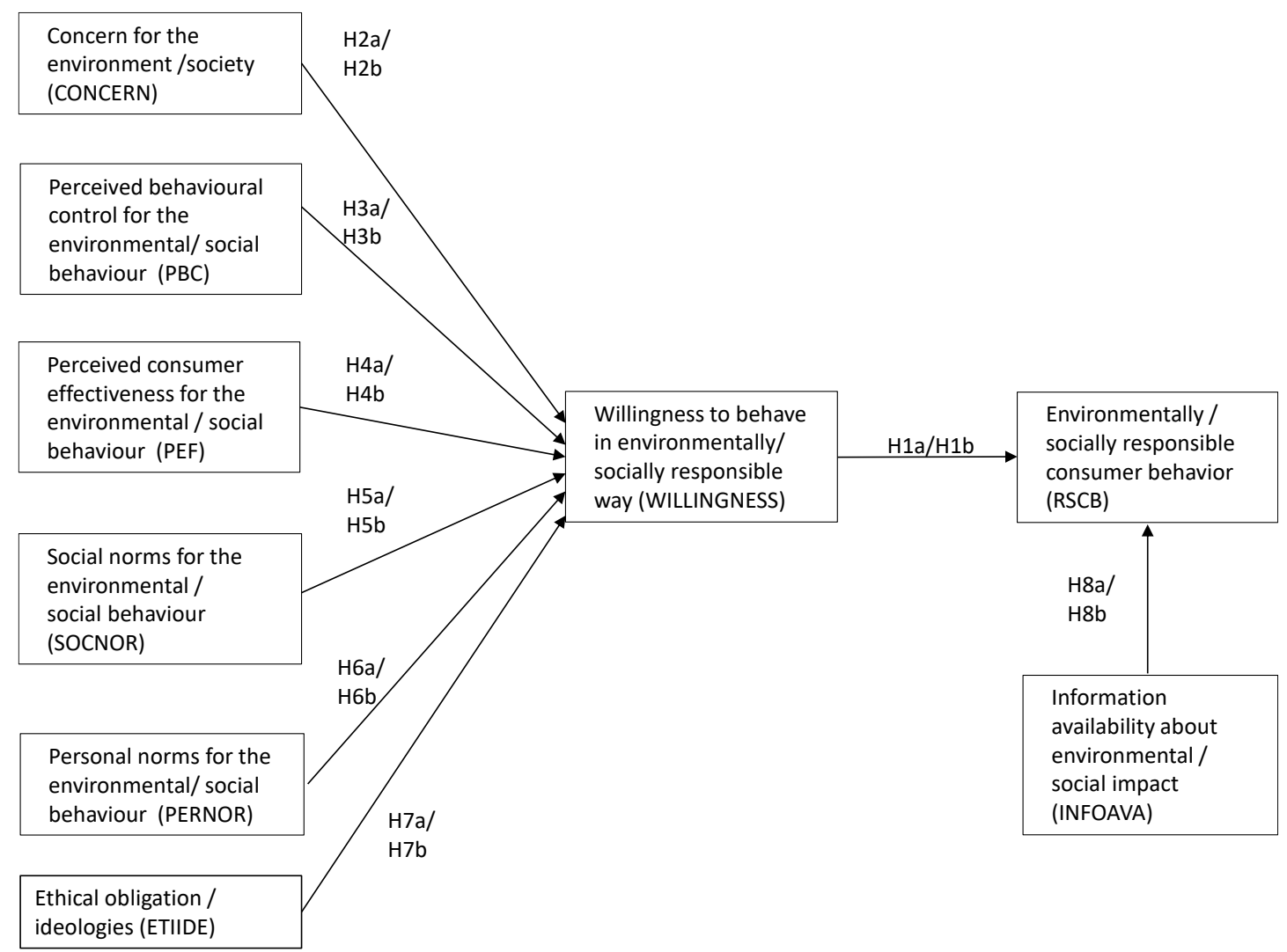




\section{EMPIRICAL STUDY}

Mixed methods were used to combine qualitative and quantitative methods to provide a more complete perspective on the researched topic (Brannen, 2005). We approached the research questions and data collection sequentially, starting with exploratory perspective by using qualitative methods. By using sequential phases "researcher may be able to give voice to diverse perspectives, to better advocate for participants, or to better understand a phenomenon or process that is changing as a result of being studied", additionally researcher can "expand an understanding from one method to another, to converge or confirm findings from different data sources" (p. 240, Creswell, 2003). The questionnaire for the quantitative research was developed based on the literature review and personal interviews. In order to properly represent domains of the constructs and ensure items reflect concepts they are intended to present, personal interviews with general population members were conducted. Webb et al. (2008) observed that the range of social and environmental issues changes and needs to be updated regularly. In absence of adequate scales for TPB variables for socially responsible sustainable consumer behavior (Webb et al., 2008), typically, a scale measuring a specific phenomenon in the environmental field was used from previous research, and then a version of social equivalent was developed.

\subsection{Study 1}

\subsubsection{Methods}

In order to illuminate meaning and understand consumer perspectives on environmental and social dimension of the TPB model constructs, we conducted in-depth interviews with consumers through framed qualitative inquiry questions. We interviewed ten individuals during two months period (age 25-65; 6 females, 4 males, high-school education or more, middle- or upper-income households, employed or retired, with or without children). For selecting participants, purposive sampling was used of respondents who could provide 
relevant information. Our focus was to gather opinions of a typical consumer with some though not an extreme - degree of environmental or social concern. Data was collected in a developed Central European country. Open-ended questions were used in order to understand and gather the subjects' opinions about their responsibilities toward themselves as consumers, the natural and social environment, their motives to act and the whole process of responsible behavior from concern to action. Respondents were prompted to talk about the most pressing problems of today's natural and social environment, about differences between issues of environmental, social and economic sustainability, and their manifestation in everyday consumption. The context of small value purchases/FMCG was more exposed in interviews than higher value products or services. Interviews lasted up to an hour and all interviewees gave their informed consent prior to their inclusion in the study and recording of the interview. Data was collected according to McCracken (1988) recommendations for long interviews and analyzed following procedures recommended by Miles, Huberman and Saldana (2014), which consist of data reduction, data display and conclusion drawing. The data reduction process began by transcription of audiotaped interviews, organization of notes and observations. Data was reduced in iterations and mixed approaches of coding were used, including descriptive and process coding (Miles et al., 2014). Coding was done manually.

\subsubsection{Results}

The majority of respondents showed some degree of concern over environmental and social issues, although they seemed better informed about environmental issues: "We know that natural environment is being exploited in hundred different ways, though stories of social misconduct are rarely mentioned, but when they do come out I give them more attention" (female, 28). To describe environmental problems they usually use words like (air or environmental) pollution, waste, climate change, global warming. Social problems are usually 
described in terms of problems with relationships and treatment of others at different levels (personal, work environment, unfairness), unemployment and poverty.

They also believed there is a lack of awareness of severity of social problems and demonstrated increased interest in social issues as a consequence of current economic situation and perceptions that society now needs more help than nature. The problem of disconnection in human relationships was described as a lack of mutual understanding, honesty, cooperation, willingness to help other people, interest in everyday human problems, ignorance, "people are treated as worthless, only money has value" (female, 63). Growing differences between poor and wealthy, unemployment and non-payment are seen as the most pressing issues. Nevertheless, nature is still seen as more vulnerable and in need of help. In addition, there is a belief that nature and humans are connected so that problems in nature (e.g. pollution) can soon become human problems (e.g. dangerous polluted food).

Interviewees in our qualitative research believe they have more knowledge about the exploitation of nature, while stories of social misconduct are less prevalent. Social injustice seems to be out of their control and has to be resolved by others, e.g., 'countries where workers' rights are violated should be responsible for creating a safe work environment' (male, 33). This was also evident when comparing fair trade with environmental behaviors like buying eco, bio or recyclable products. Fair trade products are mostly not known or vaguely known and are, for the most part, not frequently purchased. One respondent offered a comparison with recyclable products: 'Materials exist that can be recycled and you cannot lie about that, with fair trade there is still a long chain and everybody can take something so the final link (worker) still does not get 'fair share' (male, 33).

In addition, fair trade products are often not seen on the shelves; thus, availability for purchasing is limited. Environmentally responsible products (e.g. bio, eco) seem to be connected with regular purchases (e.g. food) and socially responsible products (e.g. fair trade) 
seem to be more appropriate for special occasions (e.g. chocolate for gifts). From our interviews it seems that consumers can have more direct influence through environmentally responsible consumption behaviors (e.g. recycling), compared to socially responsible consumption. According to their views, there are more possibilities for other stakeholders (governments, companies) to better control social responsibility than consumers: "Problems in society ... It seems a more distant topic, taboo topic, I think that you have more influence over nature, everyone can make a difference, it is not connected with society or government but with personal conscience" (male, 53). Consumers in our qualitative research did not report almost any social pressure to behave responsibly, especially when talking about environmentally responsible behavior. The feeling of obligation usually comes from them personally. Middle age respondent also mentions that others can quickly see one as strange if ones actions are too environmentally conscious. The common norm is that one conforms to “consumer society" and uses what is available in today's society. Our interviewees believe there is some degree of information about environmental and social impact available that can help one to make informed decisions, though they do doubt if we have all the right information for better consumption decisions and responsible behavior. "You know where the product comes from, what are the ingredients, but the most important information - the production process (e.g. fruit spraying) that influences quality and impacts nature and humans is unknown or even hidden" (male, 53).

The insights gathered were used to appropriately form social dimension constructs, usually from the equivalent from environmental dimension. For example, the concern construct was adapted based on insights that respondents see social problems connected most with unemployment, workers' rights and irresponsibility actions of some people. Similarly, equivalents based on established scales for environmental dimension were made for perceived behavioral control/effectiveness, norms, 


\subsection{Study 2}

\subsubsection{Methods}

To measure 'concern', 'willingness', 'behavior', ‘norms' and “ethical obligation”, we used scales from previous studies. Appendix provides a list of items used in our study. 'Information about the environmental/social impact' of products and companies scales was developed from an initial pool of items from the literature. Total questionnaire was tested on a sample of 21 respondents to access validity of the items. First ten questionnaires were conducted in person to assure respondents understand the questions correctly. We also tested whether the language used was clear and concise. In order to enhance the motivation of respondents to answer accurately we provided explanations of why their answers were important (MacKenzie \& Podsakoff, 2012). Minor changes were made to the questionnaire, especially regarding giving additional explanation for certain questions (e.g. giving examples of socially and environmentally responsible on several parts of the questionnaire). Willingness to behave in environmentally friendly way and environmentally friendly behavior were tested in one of our previous research on a sample of 319 respondents where we decreased the number of items from the original scales and achieved good construct validity and reliability. Items were measured on a 7-point Likert-type scale ranging from 1 (strongly disagree) to 7 (strongly agree). Questions were included in a web based panel study of a national panel provider.

Sample included 426 respondents (ages 18 to 65). Quota sampling by age, gender and location was used. The final respondent profile was representative and included 47.4 percent males and 52.6 females. 10.6 percent 18 to 25 -year-olds, 20.0 percent 26 to 35 -year-olds, 20.7 percent 36 to 45 -year-olds, 27.2 percent 46 to 55 -year-olds and 21.6 percent 56 to 65 -yearolds. Majority has finished high school (42\%) or tertiary education (44\%), smaller share has finished only primary or vocational school (14\%). Net monthly household income is up to 
1100 EUR for $24 \%$ of the sample, between 1100 EUR and 2200 EUR for $38 \%$ and above 2200 EUR for $16 \%$, (1\%, without income and $21 \%$ did not want to answer). Majority have already bought some kind of environmentally or socially responsible product $(95 \%$ energy efficient product, $94 \%$ recyclable product, $91 \%$ eco products, $93 \%$ locally produced product, $68 \%$ product that claims donations to people in need, $36 \%$ fair trade product).

Several procedural measures were included in order to minimize common method bias (MacKenzie \& Podsakoff, 2012), which can be observed in cross-sectional studies of attitudebehavior relationships, influencing construct validities, reliabilities and covariations. In order to carefully design a study and increase the ability of respondents to respond accurately, we pretested the questionnaire to ensure questions are comprehensible, provided examples of environmentally and socially responsible behaviors to increase understanding of the topic and conducted interviews to better understand the vocabulary that consumers use for describing socially responsible behaviors. We have informed respondents the survey will be used for academic research purposes and is thus lengthier as usual, which could increase their motivation to respond accurately. We have emphasized their personal opinions and experiences are important. Research was administered by computer-assisted questionnaire, thus minimizing the effect of interviewer presence and potential social desirability of answers. In addition, a single-method-factor test was conducted for the study (Podsakoff et al., 2003), using exploratory factor analysis (EFA) in SPSS with an unrotated factor solution for all the scale items used in the research model. The results yielded a seven factor solution with each factor containing an eigenvalue greater than 3, main factor accounting for $36 \%$ of the variance and all seven factors accounting for total of $59 \%$ of the variance. This suggests that a single factor does not explain the majority of the variance in the data and we do not expect common method bias to substantially influence the results. 


\subsubsection{Results}

In order to determine validity and reliability of the measurement part of the model, structural equation modelling (SEM with LISREL 9.2) was performed. For indicator loadings and results of the confirmatory factor analysis for the examined constructs, see Table 2. All items loaded at least 0.60 on their assigned factors, and composite reliabilities (C.R.) of indicators were above the recommended threshold value of 0.60 (Bagozzi and Yi 1988, see Table 2). Although AVE for constructs of concern and PBC were below 0.5 (Fornell and Larcker's (1981) conservative criterion), the composite reliabilities were greater than 0.6 and we accepted the convergent validity of these constructs as adequate. We assessed discriminant validity comparing the shared construct variances with the respective AVEs (see Tables 3 and 4). AVEs exceeded the squared correlations between the constructs (except for concern and and PBC). Additional Heterotrait-monotrait (HTMT) ratio of correlations for concern and PBC (Henseler et al., 2015) demonstrated discriminant validity with the HTMT criterion way below the 0.85 threshold ( 0.63 for concern and 0.60 for PBC). 
Table 2: Means, standard deviations for items

\begin{tabular}{|c|c|c|c|c|c|c|c|c|}
\hline & \multicolumn{4}{|c|}{ ENVIRONMENTAL DIMENSION } & \multicolumn{4}{|c|}{ OCIAL DIMENSION } \\
\hline & Mean & Std. dev. & $\lambda$ & t-value & Mean & Std. dev. & $\lambda$ & $t$-value \\
\hline \multicolumn{9}{|c|}{ 1. Concern for the environment / society (CONCERN) } \\
\hline CONI & 4.69 & 1.683 & 0.629 & - & 5.95 & 1.271 & 0.725 & - \\
\hline CON2 & 6.14 & 0.955 & 0.649 & 10.808 & 5.73 & 1.181 & 0.551 & 10.153 \\
\hline CON3 & 5.80 & 1.113 & 0.662 & 10.971 & 5.94 & 1.157 & 0.626 & 11.445 \\
\hline CON4 & 5.77 & 1.257 & 0.706 & 11.500 & 5.71 & 1.384 & 0.754 & 13.413 \\
\hline \multicolumn{9}{|c|}{ 2. Perceived behavioral control for the environmental / social behavior (PBC) } \\
\hline$P B C 1$ & 4.56 & 1.533 & 0.681 & - & 4.58 & 1.492 & 0.696 & - \\
\hline$P B C 2$ & 4.82 & 1.474 & 0.665 & 9.090 & 4.79 & 1.449 & 0.635 & 8.322 \\
\hline \multicolumn{9}{|c|}{ 3. Perceived consumer effectiveness for the environmental / social behavior (PEF) } \\
\hline PEF1 & 3.36 & 1.864 & 0.893 & - & 3.54 & 1.806 & 0.710 & - \\
\hline$P E F 2$ & 4.14 & 2.035 & 0.705 & 6.179 & 4.16 & 1.933 & 0.870 & 6.134 \\
\hline \multicolumn{9}{|c|}{ 4. Ethical ideologies for the environmental/social behavior (ETIIDE) } \\
\hline ETIIDEI & 6.08 & 1.053 & 0.724 & - & 6.37 & 0.947 & 0.795 & - \\
\hline ETIIDE2 & 5.67 & 1.182 & 0.828 & 16.679 & 5.76 & 1.143 & 0.697 & 15.307 \\
\hline ETIIDE3 & 5.96 & 1.132 & 0.845 & 17.022 & 6.32 & 0.898 & 0.887 & 20.853 \\
\hline ETIIDE4 & 5.87 & 1.164 & 0.852 & 17.165 & 6.26 & 0.917 & 0.872 & 20.427 \\
\hline ETIIDE5 & 5.88 & 1.159 & 0.807 & 16.260 & 6.30 & 0.932 & 0.764 & 17.186 \\
\hline \multicolumn{9}{|c|}{ 5. Social norms for the environmental/social behavior (SOCNOR) } \\
\hline SNORI & 3.63 & 1.613 & 0.860 & - & 3.59 & 1.588 & 0.914 & - \\
\hline SNOR2 & 3.18 & 1.588 & 0.898 & 17.652 & 3.19 & 1.571 & 0.804 & 16.619 \\
\hline \multicolumn{9}{|c|}{ 6. Personal norms for the environmental/social behavior (PERNOR) } \\
\hline PNORI & 5.06 & 1.353 & 0.797 & - & 4.78 & 1.458 & 0.782 & - \\
\hline PNOR2 & 5.30 & 1.298 & 0.799 & 18.614 & 5.03 & 1.324 & 0.802 & 18.267 \\
\hline PNOR3 & 4.93 & 1.491 & 0.919 & 22.639 & 4.67 & 1.510 & 0.915 & 21.731 \\
\hline PNOR4 & 4.58 & 1.524 & 0.846 & 20.139 & 4.93 & 1.538 & 0.818 & 18.729 \\
\hline PNOR5 & 4.97 & 1.493 & 0.891 & 21.662 & 4.77 & 1.486 & 0.926 & 22.064 \\
\hline \multicolumn{9}{|c|}{ 7. Information availability (INFOAVA) } \\
\hline IAVAl & 4.08 & 1.452 & 0.715 & - & 3.86 & 1.443 & 0.746 & - \\
\hline IAVA2 & 4.23 & 1.382 & 0.690 & 13.183 & 3.83 & 1.507 & 0.752 & 15.390 \\
\hline IAVA3 & 4.30 & 1.359 & 0.787 & 14.913 & 3.89 & 1.441 & 0.861 & 17.740 \\
\hline IAVA4 & 4.08 & 1.363 & 0.816 & 15.397 & 3.79 & 1.441 & 0.848 & 17.476 \\
\hline \multicolumn{9}{|c|}{ 8. Willingness to behave in environmentally/socially responsible way (WILLING) } \\
\hline WILLA1 & 5.10 & 1.518 & 0.765 & - & 5.36 & 1.506 & 0.659 & - \\
\hline WILLA2 & 4.46 & 1.686 & 0.711 & 14.856 & 4.74 & 1.691 & 0.641 & 11.361 \\
\hline WILLA3 & 5.38 & 1.228 & 0.773 & 16.345 & 5.20 & 1.287 & 0.765 & 13.107 \\
\hline WILLA4 & 5.26 & 1.357 & 0.859 & 18.376 & 5.50 & 1.343 & 0.750 & 12.914 \\
\hline \multicolumn{9}{|c|}{ 9. Environmentally / Socially responsible sustainable consumer behavior (RSCB) } \\
\hline BEHI & 5.16 & 1.368 & 0.766 & - & 4.78 & 1.366 & 0.818 & - \\
\hline BEH2 & 5.46 & 1.335 & 0.734 & 15.610 & 5.02 & 1.337 & 0.807 & 18.847 \\
\hline BEH3 & 4.88 & 1.446 & 0.847 & 18.419 & 4.93 & 1.406 & 0.790 & 18.303 \\
\hline BEH4 & 5.22 & 1.338 & 0.806 & 17.389 & 5.04 & 1.371 & 0.707 & 15.793 \\
\hline BEH5 & 4.32 & 1.442 & 0.681 & 14.327 & 4.46 & 1.470 & 0.614 & 13.263 \\
\hline BEH6 & 4.71 & 1.553 & 0.776 & 16.628 & 4.39 & 1.571 & 0.731 & 16.490 \\
\hline
\end{tabular}


Table 3: Inter-construct correlations and reliability estimates for environmentally responsible constructs

\begin{tabular}{|c|c|c|c|c|c|c|c|c|c|c|c|c|}
\hline \multirow[b]{2}{*}{ Construct } & \multirow[t]{2}{*}{ Mean } & \multirow{2}{*}{$\begin{array}{l}\text { Cron- } \\
\text { bach } \\
\text { alpha }\end{array}$} & \multirow[t]{2}{*}{ AVE } & \multicolumn{9}{|c|}{ Environmentally responsible constructs } \\
\hline & & & & 1. & 2. & 3. & 4. & 5. & 6. & 7. & 8. & 9. \\
\hline 1. BEHAVIOR & 4.96 & 0.890 & 0.593 & 0.897 & 0.479 & 0.347 & 0.258 & 0.026 & 0.189 & 0.365 & 0.275 & 0.461 \\
\hline 2. WILLINGNESS & 5.05 & 0.860 & 0.607 & 0.692 & 0.860 & 0.567 & 0.120 & 0.073 & 0.090 & 0.549 & 0.484 & 0.180 \\
\hline 3. CONCERN & 5.63 & 0.770 & 0.438 & 0.589 & 0.753 & 0.757 & 0.192 & 0.021 & 0.079 & 0.402 & 0.605 & 0.216 \\
\hline 4. $\mathrm{PBC}$ & 4.70 & 0.740 & 0.453 & 0.508 & 0.346 & 0.438 & 0.624 & 0.000 & 0.198 & 0.155 & 0.104 & 0.513 \\
\hline 5. PEF (r) & 3.75 & 0.770 & 0.647 & -.161 & -.270 & -.146 & 0.020 & 0.784 & 0.149 & 0.149 & 0.149 & 0.149 \\
\hline 6. SOCNOR & 3.41 & 0.870 & 0.773 & 0.435 & 0.300 & 0.281 & 0.445 & 0.100 & 0.872 & 0.267 & 0.050 & 0.373 \\
\hline 7. PERNOR & 3.39 & 0.930 & 0.725 & 0.604 & 0.741 & 0.634 & 0.394 & -.197 & 0.517 & 0.929 & 0.263 & 0.260 \\
\hline 8. ETIIDE & 5.89 & 0.910 & 0.660 & 0.524 & 0.696 & 0.778 & 0.322 & -.106 & 0.224 & 0.513 & 0.906 & 0.149 \\
\hline 9. INFOAVA & 4.17 & 0.840 & 0.568 & 0.679 & 0.424 & 0.465 & 0.716 & -.060 & 0.611 & 0.510 & 0.386 & 0.840 \\
\hline
\end{tabular}

$P B C=$ Perceived behavioral control, $P E F=$ perceived consumer effectiveness, SOCNOR $=$ Social norms, PERNOR = Personal norms,

ETIIDE = Ethical ideologies, INFOAVA = Information availability

Left part of the matrix (below diagonal) represents construct correlations, on the diagonal are composite reliabilities and squared multiple correlations right, above diagonal.

Table 4: Inter-construct correlations and reliability estimates for socially responsible constructs

\begin{tabular}{|c|c|c|c|c|c|c|c|c|c|c|c|c|}
\hline \multirow[b]{2}{*}{ Construct } & \multirow[t]{2}{*}{ Mean } & \multirow{2}{*}{$\begin{array}{l}\text { Cron- } \\
\text { bach } \\
\text { alpha }\end{array}$} & \multirow[t]{2}{*}{ AVE } & \multicolumn{9}{|c|}{ Socially responsible constructs } \\
\hline & & & & 1. & 2. & 3. & 4. & 5. & 6. & 7. & 8. & 9. \\
\hline 1. BEHAVIOR & 4.77 & 0.880 & 0.516 & 0.883 & 0.510 & 0.162 & 0.216 & 0.016 & 0.261 & 0.295 & 0.158 & 0.444 \\
\hline 2. WILLINGNESS & 5.20 & 0.79 & 0.509 & 0.714 & 0.798 & 0.371 & 0.085 & 0.047 & 0.148 & 0.402 & 0.366 & 0.127 \\
\hline 3. CONCERN & 5.87 & 0.780 & 0.448 & 0.402 & 0.609 & 0.762 & 0.010 & 0.001 & 0.019 & 0.118 & 0.537 & 0.022 \\
\hline 4. PBC & 4.48 & 0.720 & 0.444 & 0.465 & 0.292 & 0.101 & 0.614 & 0.016 & 0.207 & 0.112 & 0.005 & 0.419 \\
\hline 5. PEF (r) & 3.85 & 0.760 & 0.631 & -.128 & -.217 & 0.033 & 0.126 & 0.772 & 0.009 & 0.007 & 0.009 & 0.000 \\
\hline 6. SOCNOR & 3.39 & 0.850 & 0.741 & 0.511 & 0.385 & 0.139 & 0.455 & 0.097 & 0.851 & 0.282 & 0.032 & 0.407 \\
\hline 7. PERNOR & 4.84 & 0.930 & 0.724 & 0.543 & 0.634 & 0.344 & 0.334 & -.086 & 0.531 & 0.929 & 0.142 & 0.176 \\
\hline 8. ETIIDE & 6.21 & 0.890 & 0.650 & 0.398 & 0.605 & 0.733 & 0.071 & -.095 & 0.179 & 0.377 & 0.902 & 0.021 \\
\hline 9. INFOAVA & 3.84 & 0.88 & 0.646 & 0.666 & 0.356 & 0.147 & 0.647 & -.021 & 0.638 & 0.419 & 0.144 & 0.879 \\
\hline
\end{tabular}

$P B C=$ Perceived behavioral control, $P E F=$ perceived consumer effectiveness, SOCNOR $=$ Social norms, PERNOR $=$ Personal norms,

ETIIDE = Ethical ideologies, INFOAVA = Information availability

Left part of the matrix (below diagonal) represents construct correlations, on the diagonal are composite reliabilities and squared multiple correlations right, above diagonal. 
Following a two-step approach (Anderson \& Gerbing, 1988) the structural model was assessed in the next step and testing of research hypotheses performed. The fit of the structural model for environmental dimension is satisfactory (Chi-square $981.397(\mathrm{P}=$ 0.0000), d.f. $=498, \mathrm{RMSEA}=0.0477, \mathrm{SRMR}=0.0477, \mathrm{NNFI}=0.939, \mathrm{CFI}=0.945)$, and the model explains a significant amount of the variance of the dependent constructs: 73 percent of variance for willingness to behave and 66 percent of variance for behavior. The fit of the structural model for social dimension is also satisfactory (Chi-square $991.12(\mathrm{P}=0.0000)$, d.f. $=498, \mathrm{RMSEA}=0.0482, \mathrm{SRMR}=0.0551, \mathrm{NNFI}=0.934, \mathrm{CFI}=0.941)$, and the model explains a significant amount of the variance of the dependent constructs: 65 percent of variance for willingness and 70 percent of variance for behavior (see table 5).

Consistent with our research hypotheses, willingness to behave is positively related to consumer behavior in both environmental and social dimension (H1). Similarly, concern, personal norms, personal efficiency and ethical ideologies are all positively related to willingness in environmental and social dimension (H2, H4, H6, and H7). Availability of information has positive impact on behavior in environmental and social dimension of responsible behavior $(\mathrm{H} 8)$. These relationships are strong and positive (see Table 5). The difference between antecedents of both types of behavior is in the construct perceived behavioral control, which is positively connected to socially responsible willingness to behave (H3b). Social norms (H5) have no significant impact on either environmental or socially responsible behavior, although there is a slight tendency of positive impact on willingness to behave in socially responsible way. 
Table 5: Structural model results (and t-values)

\begin{tabular}{|c|c|c|c|}
\hline & $\begin{array}{l}\text { Environmental: } \\
\text { Standardized } \\
\text { parameter (t-value) }\end{array}$ & $\begin{array}{l}\text { Social: } \\
\text { Standardized } \\
\text { parameter (t-value) }\end{array}$ & Hypothesis \\
\hline WILLING - Behavior & $0.444(9.796)$ & $0.613(10.076)$ & $\begin{array}{l}\text { H1a (+) supported } \\
\text { H1b (+) supported }\end{array}$ \\
\hline CONCERN - Willing & $0.298(2.909)$ & $0.366(4.186)$ & $\begin{array}{l}\mathrm{H} 2 \mathrm{a}(+) \text { supported } \\
\mathrm{H} 2 \mathrm{~b}(+) \text { supported }\end{array}$ \\
\hline PBC - Willing & $-0.007(-0.119)$ & $0.110(1.958)$ & $\begin{array}{l}\text { H3a (+) not supported } \\
\text { H3b (+) supported }\end{array}$ \\
\hline PEF (r) - Willing & $-0.077(-2.675)$ & $-0.158(-4.238)$ & $\begin{array}{l}\text { H4a (+) supported } \\
\text { H4b (+) supported }\end{array}$ \\
\hline SOCNOR - Willing & $-0.041(-0.996)$ & $0.0613(1.567)$ & $\begin{array}{l}\text { H5a (+) not supported } \\
\text { H5b (+) not supported }\end{array}$ \\
\hline PERNOR - Willing & $0.476(7.116)$ & $0.301(5.904)$ & $\begin{array}{l}\text { H6a (+) supported } \\
\text { H6b (+) supported }\end{array}$ \\
\hline ETIIDE - Willing & $0.394(3.640)$ & $0.239(2.454)$ & $\begin{array}{l}\text { H7a (+) supported } \\
\text { H7b (+) supported }\end{array}$ \\
\hline INFOAVA - Behavior & $0.475(9.104)$ & $0.489(10.076)$ & $\begin{array}{l}\text { H8a (+) supported } \\
\text { H8b (+) supported }\end{array}$ \\
\hline Model Fit & $\begin{array}{l}\text { Chi-square } 981.397, \\
\text { d.f. }=498, \\
\text { RMSEA }=0.0477, \\
\text { NNFI = 0.939, } \\
\text { CFI }=0.945\end{array}$ & $\begin{array}{l}\text { Chi-square } 991.12, \\
\text { d.f. }=498, \\
\text { RMSEA }=0.0482, \\
\text { NNFI }=0.934 \\
\text { CFI }=0.941\end{array}$ & \\
\hline R2 Willingness & 0.725 & 0.648 & \\
\hline R2 Behavior & 0.660 & 0.704 & \\
\hline
\end{tabular}




\section{DISCUSSION}

Our contribution lies in conceptualizing and testing the extended model of theory of planned behavior on two dimensions of sustainable behaviors - namely socially and environmentally responsible behaviors. We have tested several antecedents of environmentally and socially responsible consumer behavior on each dimension thus providing new insights into dimensionality of the concept of sustainability. As observed by Han \& Stoel (2017, p. 100) in their meta-study of TPB, inclusion of social and environmental dimension in this type of studies is needed since "there were only two or three data sets that reported TPB relationships associated with products supporting human rights. This was in stark contrast to the reported relationships associated with products supporting environmental protection, which involved an average of 24 data sets." Our research is in line with their recommendation that future studies may assess consumer behaviors toward the environmental and social issues by testing an identical model and directly comparing how the results differ. We additionally add dimensions of responsibility (ethical ideologies) and join researchers proposing to include more other-interested motivations in TPB, traditionally explained by self-interested motivations (Shaw, Shiu \& Clarke, 2000).

We addressed our research problem by conducting a representative study and using structural equation modelling to look at relationships between variables of the theory of planned behavior model, other selected variables and behavior. The ability of our model to predict the willingness to behave (behavior) in environmentally and socially responsible way is $73 \%$ $(66 \%)$ for environmental and $65 \%(70 \%)$ for social model. This is better than traditional models on average explaining around 50\% of variance for intentions and 30\% for behavior (Bamberg \& Moser, 2007). Traditional measures of PBC and social norms add less to explain the intentions than the new constructs included, which is an interesting observation. It is evident from the model that concern, personal effectiveness, personal norms and ethical 
obligation are positively related to willingness to behave and that willingness to behave and information availability are positively related to behavior in both types of behavior, environmentally and socially responsible. This is in line with some previous research of environmentally responsible behavior (e.g. Minton \& Rose, 1997, Bamberg \& Moser, 2007). Contrary to what would be expected according to the TPB model, perceived behavioral control only has a positive impact on willingness to behave in socially responsible way and does not relate positively to willingness to behave in environmentally responsible way. Although usually a good predictor of intentions (Bamberg \& Moser, 2007), some other authors did not find the positive relationship. Tarkiainen and Sundqvist (2005) did not find the association to organic food buying intent. They measured PBC as perceived availability and importance of price and explained it might not have an effect due to good supply and low price premium on organic food. Another interpretation of this finding is based on our qualitative research. Environmentally responsible behavior can be inferred as a widespread, developed behavior that has a longer presence in the lives of consumers compared to socially responsible behavior. Therefore, with time, $\mathrm{PBC}$ might lose the importance it has on formation of intentions compared to other predictors like information availability, personal norms and ethical ideologies that become more important. Socially responsible behavior can be interpreted as a less widespread behavior, which is only entering in consumer lives and their consciousness, therefore PBC could still have some importance on formation of intentions, together with strongest predictors of information availability, concern and personal norms.

Perceived consumer effectiveness, which is a related construct to $\mathrm{PBC}$, has a positive influence on willingness to behave in both types of behavior. Thus, a feeling that individual actions count, may have a more permanent positive effect on willingness to behave in either 
environmentally and socially responsible way than a feeling of potential obstacles to a specific behavior.

In contrast to personal norms, social norms do not have a significant direct impact on willingness to behave responsibly, although in tendency, a positive impact on socially responsible willingness to behave is seen. This extends the results of other authors where it is commonly seen as the weakest predictor of the TPB model (Paul et al., 2016). Bamberg \& Moser (2007) found in the meta-study of pro-environmental behavior that social norms have a more indirect influence on intention (e.g. through moral norms). Similarly, Tarkiainen and Sundqvist (2005) found the indirect effect through attitude formation. We also give a similar explanation as in the case of $\mathrm{PBC}$, because environmentally responsible behavior has been more connected to consumer lives in the past. Social norms for socially responsible behavior might be less prevalent, socially responsible behavior less internalized and personal norms not fully developed. As Minton \& Rose (1997) observe, personal norms can be also seen as internalized social norms. This may come from the longer presence and communication campaigns for environmentally responsible products that is more visible as opposed to more currently developing appeals for socially responsible products.

The construct of ethical obligation has a larger positive effect on environmentally responsible behaviors compared to socially responsible behavior, although based on the literature we would expect a stronger effect for socially responsible behavior (Shaw, Shiu \& Clarke, 2000). Different result from the literature may be due to the fact that socially responsible consumption is different from ethical consumption (not avoiding taxes, not lying or deceiving), where ethical obligation would be more in place as antecedent of consumer behavior.

Some limitations of our study need to be mentioned. In our survey, we included general population consumers, since we wanted to capture views of more mainstream population. By 
this procedure we might have missed environmental and social attitudes which are perhaps more subtle and not easily observable in the general consumer groups. Although we did our best to emphasize the value of their answers, throughout the research, more reminders to respondents to emphasize the importance of answering accurately could have been used. Cross-sectional data collection is certainly a limitation, although due to nature of panel participation and anonymity of respondents it was not possible to contact the same respondents more than one time. We dully explained to respondents that some questions might seem similar but that each is unique and important.

Behavior was measured in general terms, not for specific category of products, similarly as Paul et al. (2016). Consumers were thus not referred to a specific product or product category, which would relate their answers to the specific category. Since the goal of the study was to advance theoretical understanding of antecedents of environmentally and socially RSCB in general, we focused on global rather than specific (i.e. product category- or brand-level) consumer responses relating to concern, willingness to behave and RSCB.

For behavior measurement, we used proxy measures of reported behavior, based on established scales (Roberts \& Bacon, 1997, Webb et al., 2008, who call it "impact purchase and use criteria"). Reported behavior is not necessarily actual behavior. To measure actual behavior, several issues would need to be considered. Geiger et al. (2018) describe one challenge as finding "a reasonable cut-off point between comprehensiveness and a manageable length" when constructing behavioral scales for sustainable consumption. They say "to capture the full impact of food-related behaviors of a person, a lot of information would have to be recorded; e.g., for the ecological impact the quantity of food eaten, the distance of food travelled etc.” (p. 28). Currently researchers are also employing new methodologies like experimental auction approach (de-Magistris, \& Gracia, 2016) and scanner data (Van Doorn \& Verhoef, 2015) to more accurately present actual consumption 
behavior. Our scales to measure for example concern for socially responsible behavior can also be included in these types of research.

Researchers are recognizing environmentally and socially responsible decisions as a "mixture of cognitions and emotions" (Park \& Stoel, 2005, p. 236), where also situational factors (Carrington, Neville, \& Whitwell, 2010) and consumer personality play an important role. These factors are usually not part of the TPB model and present a limitation of the model, but could provide additional answers for explaining sustainable consumption.

These challenges remain to be resolved in future studies. As with similar research in the field of ethics and responsible consumer behavior, a social desirability bias could play a role in the answers of consumers, thus over or under reporting certain behaviors (Carrigan and Attalla, 2001).

\section{CONCLUSIONS AND IMPLICATIONS}

In the past, researchers of sustainable consumption have put a lot more emphasis on environmental than social issues. Measures and antecedents of responsible consumption were developed that did not reflect the dimensionality of sustainable consumption, namely covering environmental and social issues. With this article, we join researchers stressing the necessity of including new understandings in the field and presenting the whole complexity of issues (Roberts, 1995; Webb et al., 2008; Catlin et al., 2017; Geiger et al., 2018).

Our aim was to determine whether consumers act differently when behaving in environmentally or socially responsible way and whether environmentally and socially responsible behavior have different antecedents. For consumers to fully embrace sustainability issues, it is crucial to understand that different issues are important. Sustainability can only be achieved by equally embracing all dimensions of sustainability, which substantially adds to the complexity of consumers' thinking and acting. "Struggles" between doing what is good for the consumer and what is good for environment/society could 
be the reason why consumers have difficulties with sustainable consumption. In general, antecedents of environmentally and socially responsible consumption are similar and consumers can be addressed in similar way with some possible exceptions (e.g. social norms). In general, personal norms, concern and ethical ideologies seem to have the strongest impact on willingness to behave responsibly which together with information availability mainly predicts responsible consumer behavior. The importance of social and personal norms and information is observed also in the recent review of several important factors to consider when trying changing consumer behavior in a more sustainable direction (White, Habib \& Hardisty, 2019). Managers can encourage sustainable responsible behavior related to environmental and social issues by encouraging personal norm development, pointing to issues that need to be of concern for consumers related to the environment and society, building awareness on ethical obligations in terms of not harming environment or other people's dignity or welfare and providing sufficient information for behavioral actions.

Our research showed the main difference between willingness to behave in environmentally and socially responsible consumer behaviors seems to be in the influence of perceived behavioral control and possibly subjective social norms. One possible reason is that environmentally responsible consumption was much more widespread and communicated by media and companies in the past. In addition to being responsible to the natural environment, environmentally responsible consumption is also beneficial to the consumer itself (e.g. health benefits). Socially responsible consumption, on the other hand, is more other-centered and should therefore be addressed differently. To raise the awareness and actions of socially responsible consumers, marketers should make effort to increase social desirability of social issues and make an effort to limit obstacles or present possible ways toward this type of behavior. Our findings call for successful sustainability programs that are aligned to consumer sustainability needs and wants. 
Results can provide some ideas for marketers and public policy makers on how to potentially increase the desirability of sustainable and responsible behavior. To raise the awareness of social issues and social actions of responsible consumers, marketers and public policy makers should try to increase the presence of social issues and limit the obstacles for this type of behavior. Their appeals should stress the social norms connected with social problems to perform socially desirable actions. For example, they could include influencers or positive examples that are admired by a specific population. For increasing sustainable responsible behavior (both environmental and social), marketers and public policy makers should also be attentive and provide consumers with enough information, increase personal norms by influencing social norms, concern and ethical ideologies. Specifically, ethical ideologies should be more stressed when trying to change the behavior of the masses, starting with young children in schools.

Further research could look more in detail if and what trade-offs consumers make when they decide between environmentally and socially responsible consumption, self- and othercentered consumption. This could be the reason why consumers do not achieve more sustainable consumption. The effect of social norms should be further studied and different measurements proposed (e.g. influence of others than important others, e.g. media, “influencers"). Further segmentation studies based on attitudes and behaviors regarding the dimensions of responsible consumption could be developed to better understand differences among consumers in their RSCB and response to antecedents of sustainable consumption.

Funding: The authors acknowledge the project "Challenges of inclusive and sustainable growth", P5-0128, was financially supported by the Slovenian Research Agency.

Conflict of Interest: The authors declare that they have no conflict of interest. 
Ethical approval: All procedures performed in studies involving human participants were in accordance with the 1964 Helsinki declaration and its later amendments or comparable ethical standards. Data involving human participants for this study was gathered in 2014, when there was no committee for ethics in research at the School of Economics and Business, University of Ljubljana (the committee was established in 2017).

This article does not contain any studies with animals performed by any of the authors.

Informed consent: Individual participants in the study were anonymized participants in a web-based panel. Access to respondents was provided by a research agency and respondents received compensation for their participation. No personal data was gathered by researchers beyond the data reported in this study (e.g., gender, age).

\section{APPENDIX: MEASUREMENT SCALE ITEMS}

\section{Concern for the environment / society (CONCERN)}

(Antil, 1984; The Socially Responsible Consumption Behavior scale (SRCB); only selected items from the original scale were used and environmental dimension was tested previously on another sample of 319 respondents, social dimension scale was adapted based on insights from interviews)

1.1 Pollution is presently one of the most critical problems facing this nation. / Unemployment is presently one of the most critical problems facing this nation.

1.2 Natural resources must be preserved, even if people must do without some products. / Workers rights must be protected, even if people must do without some products.

1.3 Pollution is personally affecting my life. / Irresponsible actions of other people are personally affecting my life.

1.4 You become incensed when you think about the harm being done to the plant and animal life by pollution. / You become incensed when you think about the harm being done to some people by irresponsible actions of other people.

\section{Perceived behavioral control (PBC)}

(adapted from Ajzen, 2013) 
2.1 If I wanted to I could easily avoid buying products that are not environmentally friendly. / If I wanted to I could easily avoid buying products that are not socially friendly.

2.2 There are likely to be little or no barriers for me in buying environmentally friendly products. / There are likely to be little or no barriers for me in buying socially friendly products.

3. Perceived consumer effectiveness (PCE) ( $r)$

(Ellen et al. (1991)

3.1 There is not much that any one individual can do about the natural environment. I There is not much that any one individual can do about the social environment.

3.2 The conservation efforts of one person are useless as long as other people refuse to conserve. / The human rights protection efforts of one person are useless as long as other people refuse to take care of human rights protection.

4. Social norms (SOCNOR)

(Thøgersen, 2006)

4.1 Most people who are important to me think that I should buy environmentally friendly products. / Most people who are important to me think that I should buy socially friendly products.

4.2 Most of my acquaintances expect of me that I buy environmentally friendly products instead of conventional product. / Most of my acquaintances expect of me that I buy socially friendly products instead of conventional product.

Original scale (Thøgersen, 2006):

Most people who are important to me think that ... (7-point scale from I should not, to I should) ... deliver my recyclable materials, such as glass packaging, newspapers and magazines, to recycling=buy organic food instead of conventional'.

Most of my acquaintances expect of me that I deliver my recyclable materials, such as glass packaging, newspapers, and magazines, to recycling=buy organic food instead of conventional as far as possible," 


\section{Personal norms (PERNOR)}

(first two items from Thøgersen, 2006, other 3 items self-made, based on qualitative research)

5.1 I feel an obligation to choose environmentally friendly products / socially friendly products.

5.2 I feel I should choose environmentally friendly products instead of conventional products. / I feel I should choose socially friendly products instead of conventional products.

5.3 I feel I have an ethical obligation to buy natural products / fair trade products.

5.4 I feel I have an ethical obligation to buy eco/bio products / local products.

5.5 I feel I have an ethical obligation to buy environmentally friendly products / socially friendly products.

Original scale (Thøgersen, 2006):

I feel an obligation to deliver my recyclable materials, such as glass packaging, newspapers and magazines, to recycling=choose organic food.

I feel I should deliver my recyclable materials, such as glass packaging, newspapers and magazines, to recycling=choose organic instead of conventional food products.

\section{Willingness to behave in environmentally conscious way (WILLINGNESS)}

(Antil, 1984; The Socially Responsible Consumption Behavior scale (SRCB; only selected items from the original scale were used and environmental dimension was tested previously on another sample of 319 respondents, social dimension scale was adapted based on insights from interviews)

6.1 I would be willing to sign a petition or demonstrate for an environmental cause. / I would be willing to sign a petition or demonstrate for a human/workers' rights cause.

6.2 I would be willing to ride a bicycle or take a bus to work in order to reduce air pollution. / I would go several miles out of your way to buy from a store that you knew cares for its employee rights.

6.3 I would donate a day's pay to a foundation to help improve the environment. / I would donate a day's pay to a foundation that improves human living conditions.

6.4 I would be willing to stop buying products from companies that are guilty of polluting the environment, even though it might be inconvenient. / I would be willing to stop 
buying products from companies that are guilty of discriminating against women, even though it might be inconvenient.

6.5 I would be willing to make personal sacrifices for the sake of slowing down pollution, even though the immediate results may not seem significant. / I would be willing to make personal sacrifices for the protections of human rights, even though the immediate results may not seem significant.

7. Environmentally/socially responsible sustainable consumer behavior (BEHAVIOR; $R S C B)$

(Roberts \& Bacon, 1997, Ecologically Conscious Consumer Behavior scale (ECCB) and Webb et al, 2008, factor 1 "CSR performance"; only selected items from the original scale were used and environmental dimension was tested previously on another sample of 319 respondents)

7.1 When there is a choice, I always choose the product that contributes to the least amount of pollution. / When I am shopping, I try to buy from companies that are working to improve conditions for their employees.

7.2 Whenever possible I buy products packaged in recyclable containers. / I try to buy from companies that hire people with disabilities.

7.3 When I purchase products, I make a conscious effort to buy those products that are low in pollutants. / I make an effort to buy products and services from companies that pay all of their employees a living wage.

7.4 When I have a choice between two equal products, I always purchase the one less harmful to natural environment. / When given a chance, I switch to brands where a portion of the price is donated to charity.

7.5 I do not buy a product if the company that sells it is environmentally irresponsible. / I do not buy a product if the company that sells it is socially irresponsible.

7.6 I have switched products for ecological reasons. / I have switched products for social reasons.

8. Information availability about environmental/social impact (INFORMATION) (self-made)

8.1 I usually verify the information given by the companies about their environmental impact / social impact. 
8.2 I usually know where to verify the information about the products environmental impact / social impact.

8.3 I know the environmental impact / social impact of products I usually buy.

8.4 I know the production process impact of environmental products / socially friendly products I usually buy.

9. Ethical obligation

(Ethics Position Questionnaire, Forsyth, 1980 in Singhapakdi, Vitell, Rallapalli, \& Kraft, 1996; selected 5 idealism items from 10 idealism and 10 relativism items, social dimension scale was adapted based on insights from interviews)

9.1 A person should make certain that their actions never intentionally harm environment even to a small degree. / A person should make certain that their actions never intentionally harm another person even to a small degree.

9.2 The existence of potential harm to environment is always wrong, irrespective of the benefits to be gained. / The existence of potential harm to other people is always Wrong, irrespective of the benefits to be gained.

9.3 One should not perform an action which might in any way threaten the dignity and welfare of animals or environment. / One should not perform an action which might in any way threaten the dignity and welfare of another individual.

9.4 If an action could harm the environment, then it should not be done. / If an action could harm an innocent other, then it should not be done.

9.5 The dignity and welfare of natural environment and animals should be the most important concern in any society. / The dignity and welfare of people should be the most important concern in any society.

\section{REFERENCES}

Abdul-Muhmin, A. G. (2007). Explaining consumers' willingness to be environmentally friendly. International Journal of Consumer Studies, 31(3), 237-247.

Ajzen, I. (1991). The theory of planned behavior. Organizational Behavior and Human Decision Processes, 50(2), 179-211.

Ajzen, I. (2013). Theory of Planned Behaviour Questionnaire. Measurement Instrument Database for the Social Science. Retrieved from www.midss.ie.

Ajzen, I. and M. Fishbein (2005). The influence of attitudes on behavior. The handbook of attitudes, 173: 221. 
Anderson, J. C., \& Gerbing, D. W. (1988). Structural equation modeling in practice: A review and recommended two-step approach. Psychological bulletin, 103(3), 411.

Anderson Jr, W. T., \& Cunningham, W. H. (1972). The socially conscious consumer. The Journal of Marketing, 23-31.

Antil, J. H. (1984). Socially Responsible Consumers: Profile and Implications for Public Policy. Journal of Macromarketing, 4(2), 18-39.

Bagozzi, Richard P. \& Youjae Yi (1988), On the Evaluation of Structural Equation Models, Journal of the Academy of Marketing Science, 16(1), 74-94.

Balderjahn, I., Buerke, A., Kirchgeorg, M., Peyer, M., Seegebarth, B., \& Wiedmann, K. P. (2013). Consciousness for sustainable consumption: scale development and new insights in the economic dimension of consumers' sustainability. AMS review, 3(4), 181-192.

Bamberg, S. (2003). How does environmental concern influence specific environmentally related behaviors? A new answer to an old question. Journal of Environmental Psychology, 23(1), 2132.

Bamberg, S., \& Moser, G. (2007). Twenty years after Hines, Hungerford, and Tomera: A new metaanalysis of psycho-social determinants of pro-environmental behaviour. Journal of Environmental Psychology, 27(1), 14-25.

Brannen, J. (2005). Mixed methods research: A discussion paper.

Belch, M. A. (1982). A segmentation strategy for the 1980's: Profiling the socially-concerned market through life-style analysis. Journal of the Academy of Marketing Science, 10(4), 345-358.

Carrigan, M., \& Attalla, A. (2001). The myth of the ethical consumer-do ethics matter in purchase behaviour? Journal of Consumer Marketing, 18(7), 560-578.

Carrington, M. J., Neville, B. A., \& Whitwell, G. J. (2010). Why Ethical Consumers Don't Walk Their Talk: Towards a Framework for Understanding the Gap Between the Ethical Purchase Intentions and Actual Buying Behaviour of Ethically Minded Consumers. Journal of Business Ethics, 97(1), 139-158.

Catlin, J. R., M. G. Luchs, et al. (2017). Consumer Perceptions of the Social Vs. Environmental Dimensions of Sustainability. Journal of Consumer Policy, 40(3), 245-277.

Chabowski, B. R., Mena, J. A., \& Gonzalez-Padron, T. L. (2011). The structure of sustainability research in marketing, 1958-2008: a basis for future research opportunities. Journal of the Academy of Marketing Science, 39(1), 55-70.

Chaiken, S. (1980). Heuristic versus systematic information processing and the use of source versus message cues in persuasion. Journal of personality and social psychology, 39(5), 752.

Choi, S., \& Ng, A. (2011). Environmental and Economic Dimensions of Sustainability and Price Effects on Consumer Responses. Journal of Business Ethics, 1-14.

Creswell, J. W. (2003). Research design: Qualitative, quantitative, and mixed methods approaches. Sage publications. 
Currás-Pérez, R., Dolz-Dolz, C., Miquel-Romero, M. J., \& Sánchez-García, I. (2018). How social, environmental, and economic CSR affects consumer-perceived value: Does perceived consumer effectiveness make a difference?. Corporate Social Responsibility and Environmental Management, 25(5), 733-747.

de-Magistris, T., \& Gracia, A. (2016). Consumers' willingness to pay for light, organic and PDO cheese: An experimental auction approach. British Food Journal, 118(3), 560-571.

De Pelsmacker, P. and W. Janssens (2007). A model for fair trade buying behaviour: The role of perceived quantity and quality of information and of product-specific attitudes. Journal of Business Ethics 75(4), 361-380.

D'Souza, C., Taghian, M., \& Lamb, P. (2006). An empirical study on the influence of environmental labels on consumers. Corporate communications: An international journal, 11(2), 162-173.

Dupré, S. (2005). Talk the walk: advancing sustainable lifestyles through marketing and communications: United Nations Environmental Programme.

Elkington, J. (1997). Cannibals with forks. The triple bottom line of 21 st century.

Elkington, J. (2004). Enter the triple bottom line. The triple bottom line: Does it all add up, 11(12), 116.

Ellen, P. S., Wiener, J. L., \& Cobb-Walgren, C. (1991). The Role of Perceived Consumer Effectiveness in Motivating Environmentally Conscious Behaviors. Journal of Public Policy \& Marketing, 10(2), 102-117.

Epstein, M. J. (2008). Making sustainability work: Best practices in managing and measuring corporate social, environmental, and economic impacts: Berrett-Koehler Publishers.

Forsyth, D. R. (1980). A taxonomy of ethical ideologies. Journal of personality and social psychology, $39(1), 175$.

Frank, P., \& Brock, C. (2019). "Green cannibalism" or an "organic inside job”? Empirical insights into the rivalry of ethical grocery types. Psychology \& Marketing, 36(6), 597-617.

Freestone, O. M., \& McGoldrick, P. J. (2008). Motivations of the ethical consumer. Journal of Business Ethics, 79(4), 445-467.

Geiger, S. M., Fischer, D., \& Schrader, U. (2018). Measuring what matters in sustainable consumption: an integrative framework for the selection of relevant behaviors. Sustainable Development, 26(1), 18-33.

Han, T. I., \& Stoel, L. (2017). Explaining socially responsible consumer behavior: A meta-analytic review of theory of planned behavior. Journal of International Consumer Marketing, 29(2), 91-103.

Henseler, J., Ringle, C. M., \& Sarstedt, M. (2015). A new criterion for assessing discriminant validity in variance-based structural equation modeling. Journal of the academy of marketing science, 43(1), 115-135. 
Kilbourne, W., \& Pickett, G. (2008). How materialism affects environmental beliefs, concern, and environmentally responsible behavior. Journal of Business Research, 61(9), 885-893.

Kim, Y., \& Choi, S. M. (2005). Antecedents of green purchase behavior: An examination of collectivism, environmental concern, and PCE. ACR North American Advances.

Kinnear, T. C., Taylor, J. R., \& Ahmed, S. A. (1974). Ecologically Concerned Consumers: Who Are They? The Journal of Marketing, 38(2), 20-24.

Kollmuss, A., \& Agyeman, J. (2002). Mind the Gap: why do people act environmentally and what are the barriers to pro-environmental behavior? Environmental Education Research, 8(3), 239260.

Lee, K. (2008). Opportunities for green marketing: young consumers. Marketing Intelligence \& Planning, 26(6), 573-586.

Leire, C., \& Thidell, A. (2005). Product-related environmental information to guide consumer purchases - a review and analysis of research on perceptions, understanding and use among Nordic consumers Journal of cleaner production, 13(10-11), 1061 - 1070

Lim, W. M. (2017). Inside the sustainable consumption theoretical toolbox: Critical concepts for sustainability, consumption, and marketing. Journal of Business Research, 78, 69-80.

Long, M. A., \& Murray, D. L. (2013). Ethical consumption, values convergence/divergence and community development. Journal of agricultural and environmental ethics, 26(2), 351-375.

Lorek, S., \& Spangenberg, J. H. (2014). Sustainable consumption within a sustainable economybeyond green growth and green economies. Journal of cleaner production, 63, 33-44.

Low, W., \& Davenport, E. (2005). Has the medium (roast) become the message?: The ethics of marketing fair trade in the mainstream. International Marketing Review, 22(5), 494-511.

Mayer, R. N. (1976). The socially conscious consumer-another look at the data. Journal of Consumer Research, 113-115.

MacKenzie, S. B., \& Podsakoff, P. M. (2012). Common method bias in marketing: causes, mechanisms, and procedural remedies. Journal of retailing, 88(4), 542-555

McCracken, G. (1988). The long interview (Vol. 13): Sage.

Miles, M. B., Huberman, A. M., \& Saldaña, J. (2014). Qualitative data analysis: A methods sourcebook. 3rd. In: Thousand Oaks, CA: Sage.

Minton, A. P., \& Rose, R. L. (1997). The effects of environmental concern on environmentally friendly consumer behavior: An exploratory study. Journal of Business Research, 40(1), 3748.

Mohr, L. A., Webb, D. J., \& Harris, K. E. (2001). Do consumers expect companies to be socially responsible? The impact of corporate social responsibility on buying behavior. Journal of Consumer Affairs, 35(1), 45-72.

Ngobo, P. V. (2011). What drives household choice of organic products in grocery stores?. Journal of Retailing, 87(1), 90-100. 
Park, H., \& Stoel, L. (2005). A model of socially responsible buying/sourcing decision-making processes. International Journal of Retail \& Distribution Management, 33(4), 235-248.

Paul, J., Modi, A., \& Patel, J. (2016). Predicting green product consumption using theory of planned behavior and reasoned action. Journal of retailing and consumer services, 29, 123-134.

Roberts, J. A. (1995). Profiling levels of socially responsible consumer behavior: a cluster analytic approach and its implications for marketing. Journal of marketing Theory and practice, 97117.

Roberts, J. A. \& D. R. Bacon (1997). Exploring the subtle relationships between environmental concern and ecologically conscious consumer behavior. Journal of Business Research, 40(1), 79-89.

Saini, R., \& Monga, A. (2008). How I decide depends on what I spend: Use of heuristics is greater for time than for money. Journal of Consumer Research, 34(6), 914-922.

Schrader, U. (2007). The moral responsibility of consumers as citizens. International Journal of Innovation and Sustainable Development, 2(1), 79-96.

Shaw, D., \& Shiu, E. (2003). Ethics in consumer choice: a multivariate modelling approach. European Journal of Marketing, 37(10), 1485-1498.

Shaw, D., Shiu, E., \& Clarke, I. (2000). The contribution of ethical obligation and self-identity to the theory of planned behaviour: an exploration of ethical consumers. Journal of Marketing Management, 16(8), 879-894.

Singhapakdi, A., Vitell, S. J., Rallapalli, K. C., \& Kraft, K. L. (1996). The perceived role of ethics and social responsibility: A scale development. Journal of Business Ethics, 15(11), 1131-1140.

Sudbury-Riley, L., \& Kohlbacher, F. (2016). Ethically minded consumer behavior: Scale review, development, and validation. Journal of Business Research, 69(8), 2697-2710.

Tarkiainen, A., \& Sundqvist, S. (2005). Subjective norms, attitudes and intentions of Finnish consumers in buying organic food. British food journal, 107(11), 808-822.

Thøgersen, J. (2006). Norms for environmentally responsible behaviour: An extended taxonomy. Journal of Environmental Psychology, 26(4), 247-261.

United Nations Environment Programme (UNEP), Sustainable consumption and production, A handbook for policy makers, Global edition, 2015. Available from https://sustainabledevelopment.un.org/content/documents/1951Sustainable\%20Consumption.p df

Uusitalo, O., \& Oksanen, R. (2004). Ethical consumerism: a view from Finland. International Journal of Consumer Studies, 28(3), 214-221.

Van Doorn, J., \& Verhoef, P. C. (2015). Drivers of and barriers to organic purchase behavior. Journal of Retailing, 91(3), 436-450.

Vermeir, I., \& Verbeke, W. (2006). Sustainable food consumption: Exploring the consumer "attitudebehavioral intention" gap. Journal of Agricultural and Environmental ethics, 19(2), 169-194. 
Webb, D. J., Mohr, L. A., \& Harris, K. E. (2008). A re-examination of socially responsible consumption and its measurement. Journal of Business Research, 61(2), 91-98.

Webster Jr, F. E. (1975). Determining the characteristics of the socially conscious consumer. Journal of Consumer Research, 188-196.

White, K., Habib, R., \& Hardisty, D. J. (2019). How to SHIFT Consumer Behaviors to be More Sustainable: A Literature Review and Guiding Framework. Journal of Marketing, 83(3), 2249. 